\title{
Frog meat microbiota (Lithobates catesbeianus) used in infant food
}

\author{
Eliane RODRIGUES ${ }^{1,2 *}$, José Teixeira de SEIXAS FILHO ${ }^{1,3}$, Silvia Conceição Reis Pereira MELLO', \\ Airton Antonio CASTAGNA ${ }^{1,2}$, Marcos Aurélio de SOUSA ${ }^{1}$, Ulisses Pereira SILVA ${ }^{1}$
}

\begin{abstract}
Captive breeding of bullfrog (Lithobates catesbeianus) is of great economic potential, mainly for its thighs and leather. The nutritional quality of frog meat includes properly balanced amino acids with a protein profile of high biological value, low fat and low cholesterol, and high digestibility due to its short chain molecule structure. It is recommended by doctors and nutritionists, especially for protein restricted children or malnourished children. Aiming to aggregate value to the segment and offer a product with nutritional properties that meet the need of children aged six months and above, a meat product based on the composition of frog meat was developed experimentally. To ensure raw material quality after bleaching and deboning, the microbiota present in the frog meat was determined. The analyses were performed according to Brazilian laws. It was observed that the resident and transient microbiota met the standards set by regulations. The results found were: mesophyll $4.5 \times 10^{4}$ CFU/g; Staphylococcus coagulase positive $2.0 \times 10^{2} \mathrm{CFU} / \mathrm{g}$; negative for Salmonella sp. and Aeromonas spp. The findings indicate that the raw material showed satisfactory sanitation even in terms of family industry.
\end{abstract}

Keywords: preschool, food security, microbiological quality of food.

\section{Introduction}

Brazil, a member of the World Health Organization (WHO) and partner of the United Nations Children's Fund (UNICEF), has implemented the National Program for Breastfeed Encouragement in Brazil (PNIAM) advising that breastfeed should be exclusive in the first six months of age and should last at least two uninterrupted years (Araújo et al., 2003). It is after the exclusive lactation period that feeding habits will influence nourishment in the upcoming years; and therefore care orientation at this age is required and essential.

Daily intake of grains, fruits, vegetables, meats, and dairy provides a balanced diet containing all nutrients children need for healthy growth and development. The Brazilian Resolution of the Collegiate Board of Directors-RDC 222/02 (Brasil, 2002) and Law number 11.265 of January $3^{\text {rd }}, 2006$ (Brasil, 2006) established the age of first infancy or early childhood, i.e, toddlers, as between 12 (twelve) months and 3 (three) years of age, emphasizing that formulas intended for infants and toddlers should aim to promote progressive adaptation to food in a balanced way that is adequate to nutritional demands meeting physiological maturity and psychomotor development.

Monte \& Giugliani (2004) concluded that complementary feeding of toddlers is critical to ensure good development and growth of the child, and, therefore, it is an essential element to meet human nutritional requirements and security and also for the development of the nation. Food security implies the right to permanent access to sufficient and nutritious food and healthy food habits corresponding to the cultural traditions of the people. For this purpose, the definitions of complementary food, "weaning food" or "supplement to breast milk", and "breast milk substitutes" were identified as those which are manufactured or prepared as a complement or supplement to breast milk or to infant formulas when those become insufficient to supplement the infant nutritional demands; they can also be defined as any food that is marketed as a partial or total replacement for breast milk, whether or not suitable for that purpose. According to The International Code of Marketing of Breast milk Substitutes, "Supplies" means quantities of a product provided for use over an extended period, free or at low price, for social purposes, including those provided to families in need (Brasil, 2006).

Mueller \& Martorel (1988) reported that since the first stages of growth, human body mass undergoes physiological changes, such as fluctuations in body composition, caused by dietary intake and hydration; therefore the quality of complementary foods in developing countries may also be associated with differential growth.

Complementary foods available in many developing countries have inadequate nutritional values or are can even be contaminated, causing increased risk of diarrheal infections, apart from offering low caloric density, which contradicts current recommendations (Marchioni et al., 2001).

After six months of age, the infant is already capable of digesting, absorbing, and metabolizing several nutrients. At this stage, breast milk alone no longer meets all nutritional needs, which makes complementary food essential.

By the end of the first year of age, most well-nourished children will have adapted to a routine of three daily meals, plus two or three snacks.

\footnotetext{
Received 1 July, 2013

Accepted 27 Jan., 2014 (006133)

${ }^{1}$ Centro Universitário Augusto Motta - UNISUAM, Rio de Janeiro, RJ, Brasil, e-mail: eli_rodrigues@terra.com.br

${ }^{2}$ Empresa de Pesquisa Agropecuária do Estado do Rio de Janeiro - PESAGRO-RIO, Niterói, RJ, Brasil

${ }^{3}$ Fundação Instituto de Pesca do Estado do Rio de Janeiro - FIPERJ, Niterói, RJ, Brasil

${ }^{*}$ Corresponding author
} 
According to Spyrides et al. (2005), the highest rate of growth in weight and length occur during the first two years of life and adolescence. The child growth chart, however, varies widely due to a complexity of factors associated with their behavior, including not only endogenous factors that comprise biological, genetic, and ethnic determinants, but also exogenous factors such as nutritional, cultural, environmental, and social statuses.

World demand for food is increasingly higher, especially for those which provide high nutritional value proteins and aggregated technological value. Frog meat-based products is a promising market alternative.

The chemical score (CS) method enables to quantify the amino acid rate by comparing it with protein quality indexes for children between two and five years of age (Food and Agriculture Organization of the United Nations; World Health Organization World Health Organization, 2007). Using this method, Pires et al. (2006) verified that frog meat has high amino acid score, with an average rating of $93,73 \%$ of real digestibility when using boneless, dehydrated meat and a Protein Efficiency Ratio (ratio between weight gain and protein consumption) of 4,43 .

Fragoso et al. (2012), studying complementary food formulation prepared using the frog's back, concluded that in addition to the use of animal carcass at low market prices, it also met the standards established by Brazilian law regarding nutritional characteristics of a product intended to toddlers, with high nutritional value and that is safe and palatable for children.

The analysis of frog meat was performed on a dry matter basis, in Lithobates catesbeianus, such as moisture (4.21\%), crude protein $(74.07 \%)$, total lipids $(9.31 \%)$, ash $(6.88 \%)$, calcium content $\left(1117.87 \mathrm{mg} \mathrm{g}^{-1}\right)$, and iron $\left(6.15 \mathrm{mg} \mathrm{g}^{-1}\right)$ for pigmented animals (Borges et al., 1987).

Its composition and differentiated nutritional value compared to those of other animal origin food, in addition to its potential use to treat certain pathologies, has encouraged the consumption of frog meat by several age groups.

The stimulus for the consumption of this kind of meat through the development of new ways of presentation and adequate commercial supply is necessary, especially at the stage when the eating habits are being formed, which will be reflected throughout the life of an individual. New formulations intended to toddlers containing frog meat as the main raw material lead to healthy habits with guaranteed nutritional value.

When producing food, one cannot disregard the factors influencing the microbial safety, a decisive issue to ensure the product's nutritional integrity and the necessary hygienic conditions, in order to avoid foodborne diseases (FBD).

Local development can be promoted in low-income communities, such as those found in the surroundings of Leopoldina Area in the city of Rio de Janeiro, through the implementation of family industries in the manufacture of this new food product with frog's back meat. It uses simple technology enabling income generation, dissemination of healthy dietary habits, and strengthening the Fluminense frog breeding by enabling the establishment of a new family industry in the state.

Therefore, this research aimed to determine the hygienic sanitary conditions of infant formulas elaborated with bull frog's back meat and easily applicable technology and are intended to toddlers and those who suffer from disorders caused by malnutrition,

\section{Materials and methods}

The present study was conducted at the experimental kitchen of the Augusto Motta University Center (UNISAM), and the chemical and microbiological analyses were performed at the State Center for Food Research, at the Agricultural Research Corporation of the State of Rio de Janeiro (PESAGRO-RIO).

A total of $2.765 \mathrm{~kg}$ of bullfrog carcass Lithobates catesbeianus was used. It was obtained from the experimental frog farm in Station of Estuarine Aquiculture Almirante Paulo Moreira (EAAPM), at Fisheries Institute of the Rio de Janeiro State (FIPERJ) in partnership with UNISUAM.

The frogs were transported to a specialized slaughterhouse, which meets the official technical standards (Brasil, 1997) an is a holder of the seal of quality from federal health inspection, and were slaughtered in accordance with the slaughtering techniques recommended by the Ministry of Agriculture, Livestock and Supply (Borges et al., 1987). The carcasses were then packed and frozen.

During the experiment at the experimental kitchen of the Augusto Motta University Center after thawing under refrigeration, the packages were weighed, and pieces of the product were taken for sample preparation. The carcasses were submitted to a bleaching process, which consists of cooking the meat from the back of the animal at a temperature of $60{ }^{\circ} \mathrm{C}$ for 15 minutes to facilitate deboning. Deboning was performed manually, typical of small scale industries, following the regulations of Good Manufacturing Practices (GMP) (Rodrigues et al., 2011).

The raw material was submitted to microbiological analysis at the State Center for Food Research /PESAGRO-RIO, following the current legislation recommendations, to obtain information necessary to evaluate the stage of freshness as recommended by GMP ensuring the hygienic and sanitary quality of the product. Physicochemical analyses of moisture, mineral, protein, and lipids were performed to verify the maintenance of its nutritional status. Thus, microbiological tests were conducted involving the search for Salmonella sp., Staphylococcus coagulase positive and Aeromonas sp and mesophilic count, using the method established by "International Commission on Microbiological Specifications for Foods" - I.C.M.S.F (1988), the "Compendium of Methods for the Microbiological Examination of Foods" of the American Public Health Association" - APHA (1984), and the guidelines recommended in the "Generic HACCP Plan for Animal Product Industries" of the Ministry of Agriculture, Livestock and Supply (Brasil, 1998). 
Aeromonas sp. counts is not mandatory according to the Brazilian law, but due to the increasing number of cases of food poisoning worldwide caused by this microorganism (which has water as its natural habitat) and recommendations of World Health Organization (WHO) for especial care with this bacteria genus, this test was included in the analysis. Moreover, microbiological quality standard, which is not mandatory for frog meat in natura according to the Brazilian law either, was included as a preventative measure to detect possible contamination of raw material, considering that temperature during the bleaching process favors the growth of such microorganism. The people handling the materials involved in the experiment wore appropriate clothing, gloves, cap, and a face mask. The tools and utensils used in the product preparation were cleaned and sanitized. The physicochemical evaluations conducted, moisture, ash, protein, and lipid, followed methodology established by the Association of Official Analytical Chemists (1997), Adolfo Lutz Institute (1985), and National Laboratory of Animal Reference Guide (Brasil, 1981).

Part of the meat $(100 \mathrm{~g})$ removed from the back of the animals was minced, homogenized using a processor, and kept under refrigeration $\left(2^{\circ} \mathrm{C}\right)$ during the time of analysis $(24$ hours), as described by the AOAC, Adolfo Lutz Institute, and National Laboratory of Animal Reference Guide. Total nitrogen was determined by the micro Kjeldahl method according to Association of Official Analytical Chemists (1997), and to express the result in protein, the conversion factor 6.25 was used, as proposed by Jones (1941).

The microbiological results obtained were compared to the microbiological standards as recommended by the Resolution RDC No. 12 of ANVISA (Brasil, 2001) for microorganisms of frog meat, but the presence of other microorganisms that indicate the sanitary and epidemiological quality was also investigated.

\section{Results and discussion}

\subsection{Processing protocol}

The heating of the frog meat back (bleaching) at $60^{\circ} \mathrm{C}$ for 15 minutes, allowed to maintain the suitable structure and integrity of composition and nutritional quality of raw material, confirmed by the comparative analysis results of moisture, ash, protein, and lipids.

The hygiene practices during the product preparation mentioned above prevented cross-contamination of the material ensuring proper sanitary conditions.

\subsection{Microbiological analysis}

The microbial profile of the microbiological analysis of the raw material, frog' back meat after bleaching, is shown in Table 1

The values observed in this study were in agreement with those established by current legislation for frog meat in natura refrigerated or frozen, as described in the resolution RDC number 12 of the National Agency of Sanitary Surveillance - ANVISA (Brasil, 2001), but they do not agree with the findings of Barreira et al. (2011), who, analyzing 30 frozen carcasses
Table 1. Analysis of the microbiota found in the meat of the back of bullfrog manipulated and removed from the rib and bleached for the preparation of food intended for toddlers.

\begin{tabular}{|c|c|c|}
\hline $\begin{array}{c}\text { Microbiological analysis } \\
\text { (25 g of meat) }\end{array}$ & $\begin{array}{l}\text { Shredded } \\
\text { frog meat }\end{array}$ & Legislation \\
\hline Mesophyll count (UFC/g) & $4,5 \times 10^{4}$ & * \\
\hline Staphylococcus coagulase-positive & $2,0 \times 10^{2}$ & $10^{3}$ \\
\hline Salmonella sp (UFC/25g) & negative & negative \\
\hline Aeromonas spp. (UFC/g) & negative & ** \\
\hline
\end{tabular}

Table 2. Physicochemical analysis of the meat of the back of bullfrog removed from the rib bleached for the preparation of food intended for toddlers.

\begin{tabular}{ccccc}
\hline Umidity & Ashes & Protein & Lipids & Calories \\
\cline { 1 - 4 } $\mathrm{c} / 100 \mathrm{~g}$ & \\
\hline 80,30 & 1,2 & $17,80^{\star}$ & $0,41^{*}$ & $74,89 \mathrm{kcal} \mathrm{313,04 \textrm {kJ }}$ \\
\hline
\end{tabular}

${ }^{\star}$ Dry matter results.

acquired from local markets in Rio de Janeiro, detected the presence of Salmonella sp. in 10\% and counting of Staphylococcus coagulase-positive of above $10^{3}$. The absence of Aeromonas sp. indicated that animal breeding premises were salubrious regarding water quality. Mesophyll counting indicated that the product had satisfactory sanitary quality.

\subsection{Physicochemical analysis}

The microbial profile of the physicochemical analysis of the raw material, meat from the back of the bullfrog after bleaching, is shown in Table 2.

Values are compatible with the those found by Gonçalves \& Otta (2008) and Nóbrega et al. (2007) for frog meat in natura, demonstrating that there was no nutritional loss from the bleaching process used.

\section{Conclusion}

The technological process used for deboning the back of the frog enabled to keep the nutritional quality without any cross-contamination or development of exacerbation of the resident microbiota.

The sample was in perfect hygienic and sanitary condition for preparation of food product suitable for human consumption.

It is possible to add value to bullfrog meat of low market price by enabling its use in food intended for toddlers.

The process developed in this study can be easily performed by newly qualified professionals thus enabling local development through the use of simple technology for the preparation of food for toddlers.

\section{Acknowledgements}

The authors wish to acknowledge the financial support and the grant of the Scientific Initiation Scholarship by the Carlos Chagas Foundation for Research Support (FAPERJ). 


\section{References}

American Public Health Association - APHA. (1984). Compendium of methods for the microbiological examination of foods (2nd ed.). Washington: Marvin L. Speck.

Araújo, M. F. M., Fiaco, A. D., Werner, E. H., \& Schmitz, B. A. S. (2003). Incentivo ao aleitamento materno no Brasil: evolução do Projeto Carteiro Amigo da amamentação de 1996 a 2002. Revista Brasileira de Saúde Materno Infantil 3(2), 195-204. http://dx.doi.org/10.1590/ S1519-38292003000200010

Association Of Official Analytical Chemists - AOAC. (1997). Official methods of analysis. 16th ed. Gaithersburg.

Barreira, V. B., Mesquita, E. F., \& Franco, R. M. (2011). Análise bacteriológica de carne de rã touro (Litobhates castebeianus) comercializada no município do Rio de Janeiro, Estado do Rio de Janeiro, Brasil. Revista Higiene alimentar, 25, 145-150.

Borges, G. F., Costa Junior, G. A., \& Teixeira, R. D. (1987). Técnicas de Abate de Rãs, como perspectivas de um melhor aproveitamento higiênico-sanitário dos produtos obtidos. Informativo técnico 86/87. Brasília: Ministério da Agricultura, Pecuária e Abastecimento. 12 p.

Brasil. Ministério da Agricultura e do Abastecimento. Secretaria de Defesa Agropecuária. Departamento de Inspeção de Produtos de Origem Animal. (1997). Regulamento da Inspeção Industrial e Sanitária de Produtos de Origem Animal (RIISPOA). Aprovado pelo Decreto n. 30.691, 29/03/52, alterado pelos Decretos no 1255 de 25/06/62, 1236 de 02/09/94, 1812 de 08/02/96 e 2244 de 04/06/97. Diário Oficial da República Federativa do Brasil, 06 maio.

Brasil. Ministério da Agricultura, Pecuária e Abastecimento. Delegacia Federal de Agricultura do Rio de Janeiro. (2001). Serviço de Fiscalização e Fomento da Produção Animal. Brasília. Retrieved from http://www.agricultura.gov.br/html/contas/rj_sffa.htm.

Brasil. Ministério da Agricultura, Pecuária e Abastecimento. Secretaria Nacional de Defesa Agropecuária. Departamento de Inspeção de Produtos de Origem Animal. (1998). Manual Genérico de Procedimentos para APPC em Indústrias de Produtos de Origem Animal. Brasília: Ministério da Agricultura, Pecuária e Abastecimento.

Brasil. Ministério da Agricultura. Secretaria Nacional de Defesa Agropecuária. Laboratório Nacional de Referência Animal. (1981). Métodos analíticos oficiais para controle de produtos de origem animal e seus ingredientes: II - Métodos físicos e químicos. Diário Oficial da República Federativa do Brasil, out. 13.

Brasil. Ministério da Saúde, Agência Nacional de Vigilância Sanitária. (2001). Resolução RDC no 12 de 02/01/01. Regulamento técnico sobre padrões microbiológicos para alimentos. Diário Oficial da República Federativa do Brasil, jan 10. Seção 1, n. 7, p. 45-53.

Brasil. Ministério da Saúde. Diretoria Colegiada da Agência Nacional de Vigilância Sanitária. (2002). Resolução RDC no 222 de 05/08/ 2002. Dispõe sobre a Promoção Comercial dos Alimentos para Lactentes e Crianças de Primeira Infância. Diário Oficial da República Federativa do Brasil, ago 06. Seção 1, n. 150, p. 558-560.

Brasil. Ministério da Saúde. Secretaria de Atenção à Saúde. Departamento de Atenção Básica. Coordenação Geral da Política de Alimentação e Nutrição. (2006). Guia alimentar para a população brasileira: promovendo a alimentação saudável. Série A. Normas e Manuais Técnicos. Brasília. Retrieved from http://dtr.saude.gov.br/ nutricao/documentos/guia_alimentar_conteudo.pdf.

Food and Agriculture Organization of the United Nations - FAO, \& World Health Organization - WHO. (2007). Protein and amino acid requirements in human nutrition. Report of a Joint WHO/FAO/UNU Expert Consultation. Retrieved from http://whqlibdoc.who.int/trs/ WHO_TRS_935_eng.pdf.

Fragoso, S. P., Moura, O. M., Casali, A. P., Costa, A. R., \& Pereira, R. F. (2012). Características físico-químicas da carne de rã-touro (Lithobates catesbeianus) liofilizada. Ciência e Tecnologia de Alimentos.

Gonçalves, A. A., \& Otta, M. C. M. (2008). Aproveitamento da carne da carcaça de rã-touro gigante no desenvolvimento de hambúrguer. Revista Brasileira de Engenharia de Pesca, 3(2), 28-30.

Instituto Adolfo Lutz. (1985). Normas Analíticas do Instituto Adolfo Lutz: Métodos químicos e físicos para análise de alimentos. 3. ed. São Paulo: IAL.

International Commission on Microbiological Specifications for Foods - ICMSF. (1988). Microorganisms in foods: their significance and methods of enumeration (2nd ed.). Toronto: University of Toronto Press.

Jones, D. B. (1941). Factors for converting percentages of nitrogen in foods and feeds into percentage of protein (11th ed.). United States Department of Agriculture.

Marchioni, D. M., Latorre, M. D. O. R., Szarfarc, S. C., \& De Souza, S. B. (2001). Complementary feeding: study on prevalence of food intake in two health centers of São Paulo. Archivos Latinoamericanos de Nutrición, 51, 161-166.

Monte, C. M. G., \& Giugliani, E. R. J. (2004). Recomendações para alimentação complementar da criança em aleitamento materno. Jornal de Pediatria, 80(5), suppl. http://dx.doi.org/10.1590/S002175572004000700004

Mueller, W. H., \& Martorel, R. (1988). Reability and accuracy of measurement. In T. G. Lohmann, A. F. Roche, \& R. Martorell (Ed.), Anthropometric Standardization Reference Manual (pp. 83-86). Champaign: Human Kinetics Books.

Nóbrega, I. C. C., Ataíde, C. S., Moura, O. M., Livera, A. V., \& Menezes, P. H. (2007). Volatile constituents of cooked bullfrog (Rana catesbeiana) legs. Food Chemistry, 102, 186-191. http://dx.doi. org/10.1016/j.foodchem.2006.05.047

Pires, C. V., Oliveira, M. G. A., Rosa, J.C., \& Costa, N. M. B. (2006). Qualidade nutricional e escore químico de aminoácidos de diferentes fontes proteicas. Ciência e Tecnologia de Alimentos, 26, 179-187. http://dx.doi.org/10.1590/S0101-20612006000100029

Rodrigues, E., Grootemboer, C., Mello, S. C. R. P., \& Castagna, A. A. (2011). Alimentos: Manual de Boas Práticas de Fabricação (n. 26). Rio de Janeiro: Programa Rio Rural.

Spyrides, M. H. C., Struchiner, C. J., Barbosa, M. T. S., \& Kac, G. (2005). Efeito das práticas alimentares sobre o crescimento infantil. Revista Brasileira de Saúde Materno Infantil, 5(2). http://dx.doi.org/10.1590/ S1519-38292005000200002 